CENTRE FOR

CLOBAL

Centre for Global Higher Education working paper series

\title{
Massification of higher education: challenges for admissions and graduate employment in China
}

\section{Ka Ho Mok and Jin Jiang}

Working paper no. 5 July 2016 
Published by the Centre for Global Higher Education,
UCL Institute of Education, London WC1H OAL

\author{
www.researchcghe.org \\ (c) Centre for Global Higher Education 2016
}

ISSN 2398-564X

The Centre for Global Higher Education (CGHE) is the largest research centre in the world specifically focused on higher education and its future development. Its research integrates local, national and global perspectives and aims to inform and improve higher education policy and practice.

CGHE is funded by the Economic and Social Research Council (ESRC) and the Higher Education Funding Council of England (HEFCE), and is a partnership led by the UCL Institute of Education with Lancaster University, the University of Sheffield and international universities Australian National

University (Australia), Dublin Institute of Technology (Ireland), Hiroshima

University (Japan), Leiden University (Netherlands), Lingnan University (Hong Kong), Shanghai Jiao Tong University (China), the University of Cape Town (South Africa) and the University of Michigan (US).

The support of the Economic and Social Research Council (ESRC) and the Higher Education Funding Council of England (HEFCE) is gratefully acknowledged.

This working paper is part of Research Programme 1. 'Globalisation, UK higher education and the public contributions of HEls'.

The present paper will be published as a book chapter in Mok, K. H. (ed.) Managing international connectivity, diversity of learning and changing labour markets (Springer, forthcoming 2016). 


\title{
Massification of higher education: challenges for admissions and graduate employment in China
}

\author{
Ka Ho Mok and Jin Jiang
}

Contents

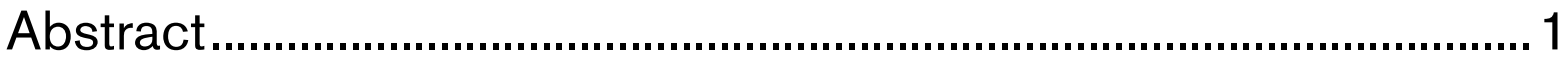

1. Massification of higher education: a growing trend in Asia and

China 2

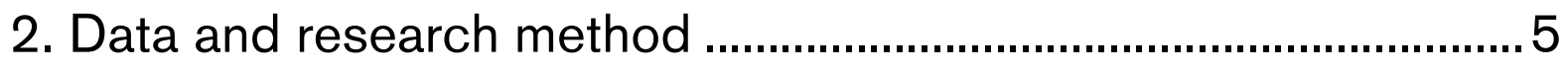

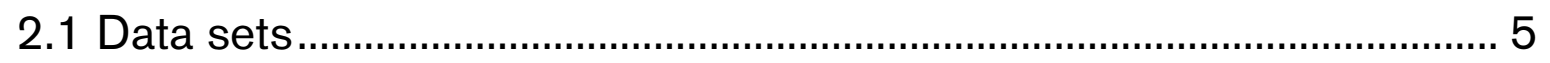

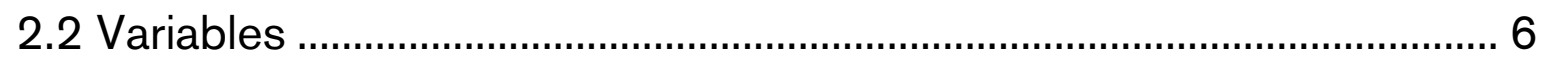

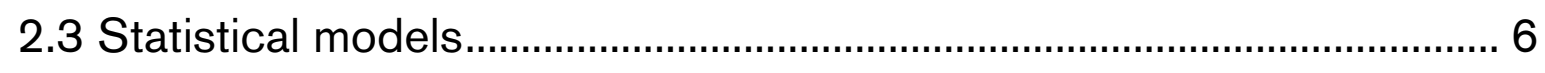

3. Increasing inequality in higher education admissions................... 7

3.1 Previous studies on educational inequality in China.............................. 7

3.2 The rising importance of a family's educational and economic resources .............................................................................................. 8

3.3 Explanations: positional values or labour market incentive .................11

4. Declining opportunity in graduate employment........................... 14

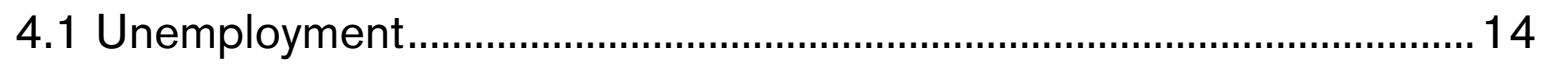

4.2 Stagnation in social mobility .............................................................17

4.3 The importance of family background on employment: subjective

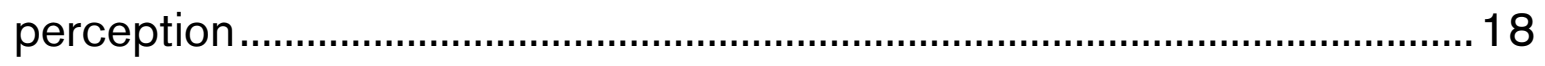

4.4 The importance of family background on employment: objective reality 
4.5 Youth expectations of social mobility...

5. Discussion and conclusion: reconstructing new education governance frameworks in promoting education equality 23

References 25 


\title{
Massification of higher education: challenges for admissions and graduate employment in China
}

\author{
Ka Ho Mok and Jin Jiang
}

Ka Ho Mok, Department of Sociology and Social Policy, Lingnan University, Hong Kong, and International Co-Investigator, Centre for Global Higher Education (email: kahomok@In.edu.hk); J. Jiang, Department of Sociology and Social Policy, Lingnan University, Hong Kong (jjiang@In.edu.hk).

\section{Abstract}

With a strong conviction to transform the country and prepare its people to cope with the growing challenges of the globalising market, the Chinese government has actively increased higher education opportunities. The higher education system has experienced a transformation from elite to mass form. The massification of higher education has provided more and more access to junior colleges and universities, and subsequently produced a growing number of college graduates looking for jobs in the labour market. Similar to other East Asian countries/economies (like South Korea, Taiwan and Hong Kong), the strong impacts of China's expansion of higher education on admission and the labour market are expected to become apparent. College students have begun to doubt the effect of higher education massification on bringing more equality in admission and on improving their competitiveness in the job market. This, in turn, leads to a widespread dissatisfaction with higher education development in China. This paper recognises that students coming from different family backgrounds may confront diverse experiences in higher education admission, graduate employment, and opportunity for upward social mobility. Yet it sets out - against the policy context highlighted above - to critically examine the impact of the massification of higher education on admissions, and subsequently on graduate employment and social mobility in contemporary China. In the final section, this paper also reflects upon reconstructing new education governance frameworks to promote educational equality in instances where higher education is massively expanded. 


\section{Massification of higher education: a growing trend in Asia and China}

Similar to the way the higher education system has moved from catering to the elite to a state of massification, and even post-massification in Western countries, the AsiaPacific region has witnessed an unprecedented growth in higher education over the past decades, in particular from the 1980s onward (Hawkins, Mok and Neubauer 2014). Believing that increasing higher education enrolment would improve the quality of the population and enhance national competitiveness in the globalising world, South Korea, Japan, Taiwan and even Hong Kong and mainland China have recorded a dramatic expansion in higher education. This has been coupled with increasingly privatised and marketised strategies to create education opportunities to meet the pressing demand for higher education (Mok 2016; Mok and Han 2015) (see Figure 1).

Figure 1 Expansion of higher education in selected Asian countries/areas (1999-2012)

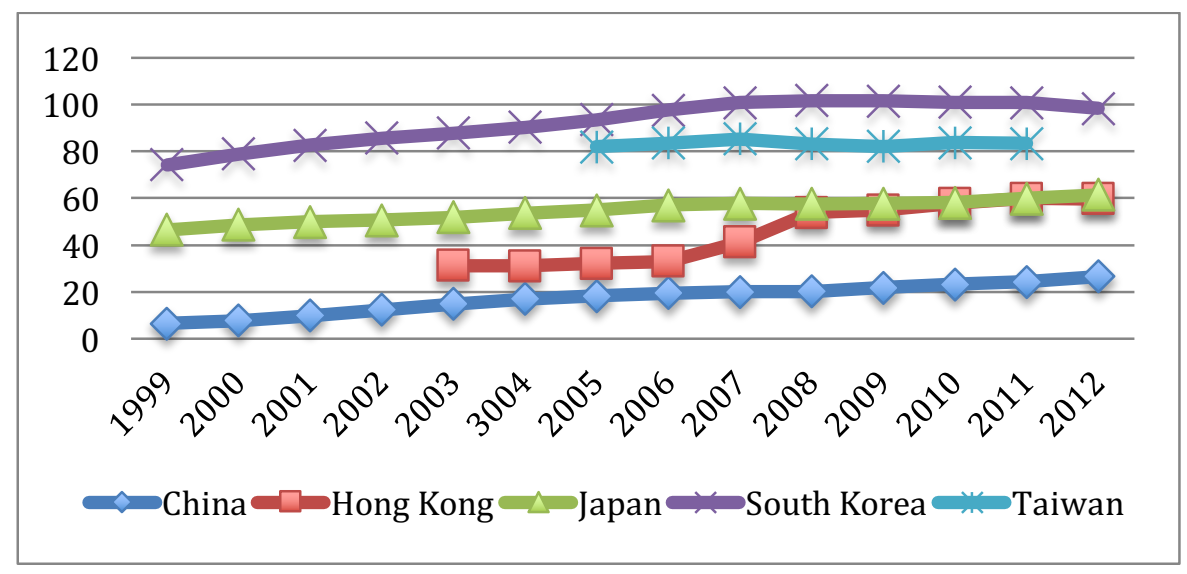

Source: UNESCO Database, http://data.uis.unesco.org; http://www.studyintaiwan.org/living statics.html

Being a latecomer to higher education development, China has made serious attempts to expand higher education enrolment in the last few decades. According to 'The Action Plan to Vitalize Education in the 21st Century' (Ministry of Education of the People's Republic of China [MOE] 1998), the government aimed to achieve a gross enrolment rate of 15 per cent by 2010, and later adjusted that goal when it reached it five years early, in 2005. In early 1999, MOE pledged to have an increase of 20 per cent in college enrolments (including junior and four-year college - 'college', 'university' and 'higher education' are used interchangeably hereafter), and revised the plan to a target increase of 47 per cent (Wan 2006). A dramatic increase in higher education opportunities has been taking place in China since 1998. 
Figure 2 (page 3 ) shows China's cohort trend of higher education expansion during 1988-2012, which covers the period before and after college expansion. The connected dotted line represents higher education enrolment, which is measured by the number of students admitted to university. Higher education enrolment indicates the system capacity. It is worth noting that the capacity showed a smooth increase from 0.67 million in 1988 to 1.08 million in 1998, and then surged from 1.6 million in 1999 to 6.89 million in 2012 - more than 10 times in number within 25 years. The solid line represents the higher education enrolment rate, which is measured by the higher education enrolment in a specific year relative to the cohort size - the number of students enrolled in primary education in the corresponding year ${ }^{1}$. The enrolment rate reflects the relative opportunity for students within the same age cohort. The cohort trend of enrolment rate is similar to that of higher education enrolment: it increased slowly in 1988-98, and then leapt in 1999 - increasing from 5.8 per cent in 1998 to 8.7 per cent in 1999. The enrolment rate grew to 35.7 per cent in 2012, more than 10 times the rate in 1988 (3 per cent), and almost seven times the rate in 1998 - the last year before the big bang. China has therefore been undergoing dramatic higher education expansion in terms of system capacity and relative opportunity.

According to Trow's definition of three-stage higher education development (Trow 1973), China's higher education system experienced a transformation from elite to a mass form in a short period of time. ${ }^{2}$ Access to higher education has moved from being a benefit for the elite to a means by which members of the general population can improve their life chances. However, the massification of higher education does not guarantee more equal opportunities in higher education admission: for example, the maximally maintained inequality perspective (Raftery and Hout 1993) and the effectively maintained inequality perspective (Lucas 2001) are influential studies suggesting that educational inequality persists despite massive educational expansion. In addition, early cohorts of college students caught up in massification were predicted to flood the labour market in recent years, thus increasing the proportion of college-educated workers. The effect of the massification of higher education on the labour market is therefore expected to emerge.

\footnotetext{
${ }^{1}$ The statistics on the size of age cohort are not available. This study uses the number of students enrolled in primary school as the proxy for students at school age, as China implemented compulsory education in 1986.

${ }^{2}$ According to Trow's indicator of higher education development (the gross enrolment rate, i.e. the percentage of an age-group enrolling in higher education), the cut-off point of enrolment rate between elite and mass higher education is 15 per cent, and that between mass and universal education is 50 per cent.
} 
Figure 2 National enrolments and enrolment rate of higher education, 1989-2012

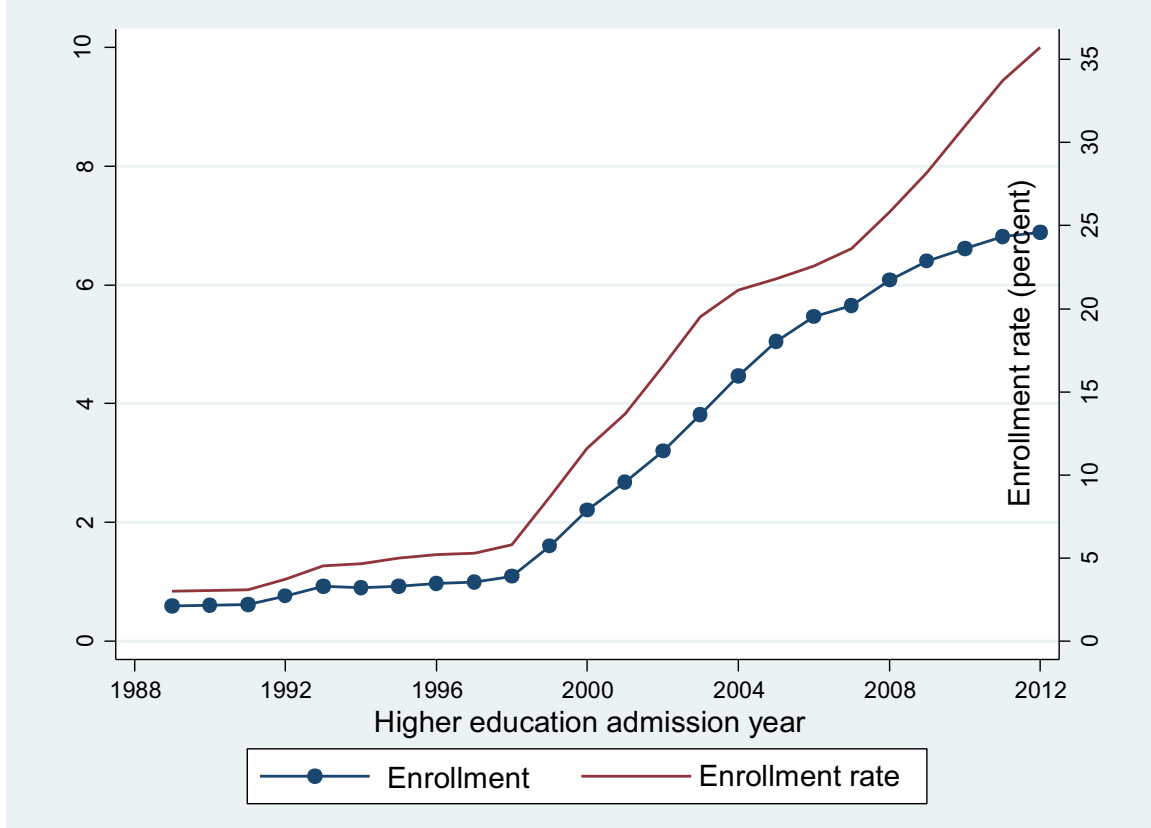

Source: Educational Statistics Yearbook of China, 1982-2012.

Note: Enrolment of higher education is measured by the number of students admitted to regular higher education institutions. Enrolment rate of higher education is measured by the enrolment of higher education relative to the cohort size of the same age. The number of graduates from primary education is used as the proxy for the cohort size, as the direct measure of cohort size is not available.

This paper sets out to critically examine the impact of the massification of higher education on higher education admissions and the labour market (especially employment of graduates from junior and four-year colleges) while taking into account socio-economic perspectives. Whether this massification brings more equal opportunities or creates greater challenges for higher education admissions and graduate employment forms the core research focus in the present study. 


\section{Data and research method}

\subsection{Data sets}

This study draws on both macro-level and micro-level data from multiple sources. The micro-level data are mainly based on pooled nationally representative data - the 2006 and 2008 Chinese General Social Survey (CGSS). ${ }^{3}$ Bian and Li (2012) have detailed documentation of the research design, sample properties, and quality control of the Chinese General Social Survey (CGSS) from 2003 to 2008. CGSS 2006 and 2008 cover most provincial-level divisions in mainland China, except for three of the remotest and sparsely populated provinces: Ningxia, Qinghai and Tibet. ${ }^{4}$ The analysis sample of CGSS 2006 and 2008 is based on respondents born in 1971-89 (assumed to be the 1989-2007 higher education admission cohorts). We restricted the sample of respondents to those who started school after the Cultural Revolution (1966-76), so that it avoids the complications prior studies found in regards to the Cultural Revolution, with its dramatic and unique effects on the educational attainment of a whole generation of Chinese (Deng and Treiman 1997; Zhou, Moen and Tuma 1998). The sample for higher education admissions consists of 4,604 respondents born in 1971-89, and the sample for analysis for employment consists of 1,445 respondents entering the labour market during 1991-2008.

We also extracted micro-level data from the 'Youth Survey of Graduate Employment and Social Mobility in Greater China 2012-2013' (Youth Survey hereafter). This survey project examines how university students in Hong Kong, Taipei and Guangzhou, three major cities in the Greater China region, evaluate their job prospects and perceive social opportunity and mobility. Our present analysis is based on the data collected in Guangzhou. Questionnaires were distributed to 1,200 college students at six different colleges/universities in Guangzhou. To ensure a balanced representation, we used stratified sampling and cluster sampling in stages one and two, respectively. In the first stage, stratified sampling was used to select six universities/colleges in Guangzhou. In the next stage, cluster sampling was used to distribute the questionnaire to college students at the selected universities/colleges. These two sampling strategies should have provided a good representation of the target population, despite the moderate response rate.

The macro-level data are drawn from the annual issues of the China Labour Statistical Yearbook, 1996-2012. The national official statistics provide information on the changes

\footnotetext{
${ }^{3}$ The data are collected and distributed by the National Survey Research Center at Remin University of China (http://www.cssod.org).

${ }^{4}$ CGSS 2006 excludes Ningxia, Qinghai, and Tibet, while CGSS 2008 excludes Qinghai and Tibet.
} 
of labour market conditions, including employment and unemployment figures for adults and college graduates.

\subsection{Variables}

We focus on the regression analysis in higher education admissions. The main dependent variable is a binary variable: whether a respondent attended higher education ( $0=$ no higher education, $1=$ any higher education). The main independent variables at the individual level are related to a respondent's family background. A father's education and occupational status reflect a family's cultural capital and economic resources, respectively. A father's education is defined as years of schooling (6 = primary, 9 = lower secondary, 12 = upper secondary, $15=$ junior college, $16=$ fouryear college, 19 = graduate school). A father's occupational status is measured by the International Socio-economic Index (ISEI), which the CGSS recorded using the 1988 International Standard Classification of Occupation (ISCO88) (Ganzeboom, de Graaf and Treiman 1992; Ganzeboom and Treiman 1996). Both a father's education and ISEI are further rescaled to a unit range of 0-1 from minimum to maximum.

A respondent's hukou (household registration) of origin is measured by his/her father's hukou (for CGSS 2006) or his/her hukou (CGSS 2008) at age 14 - following the definition of prior studies regarding a respondent's original hukou status (e.g Wu and Treiman 2004, 2007). ${ }^{5}$ The higher education admission cohort is imputed based on an individual's birth year ${ }^{6}$ and then rescaled into the unit of a decade, ranging from 0 to 1.8 , corresponding to birth years from 1971 through to 1989. This study also includes gender $(0=$ male, $1=$ female $)$ as a control variable. For the analysis of graduate employment, we have some descriptive analyses based on national official statistics and some survey questions from CGSS 2008 and the Youth Survey. We will explain the corresponding measures in the graduate employment section.

\subsection{Statistical models}

The statistical analysis of this study is mainly based on binary logistic regression models of college attendance. As we want to examine the cohort trend of inequality in higher education admission, our focus is the interaction between cohort and family background effects (measured by a father's education and a father's SEI).

\footnotetext{
${ }^{5}$ The survey questions of hukou origin of CGSS 2006 and 2008 are slightly different.

${ }^{6}$ The college entry cohort is imputed as the year when the individual was 18 years old because: (1) age six is eligible for entry to primary school, (2) six years of primary schooling, (3) three years of lower secondary education and upper secondary education, respectively.
} 
Specifically, the model is as follows:

$\ln \left(\frac{p}{1-p}\right)=\alpha$ Origin $+\beta$ Cohort $+\lambda$ Origin $\times$ Cohort $+\theta$ Hukou $+\varphi$ Gender

where $p$ denotes the probability of college attendance, Origin includes a father's education or occupational SEI. $\alpha$ and $\beta$ are the coefficients of the main effects of Origin and Cohort, respectively. $\lambda$ denotes cohort trend of the Origin. $\theta$ and $\varphi$ are the coefficients of the control variables of Hukou and Gender.

Sampling weights of CGSS 2006 and 2008 are used to correct for oversampling and to compute figures representative of the general population in China. In addition, robust standard errors are reported. The analyses are mainly implemented with Stata 12.

\section{Increasing inequality in higher education admissions}

\subsection{Previous studies on educational inequality in China}

While higher education has been expanding dramatically around the world over several decades, scholars are interested in the question of how this expansion affects educational inequality in higher education admissions: that is, the impact of expansion on the effects of family background (i.e., parental resources and conditions) on higher education attendance. Yang (2006) suggests that the educational inequality in higher education increases during expansion by analysing the parental occupation composition of the students in several colleges before and after college expansion. Drawing on the Chinese General Social Survey 2003, Liu (2006) yields similar findings, and notes that the family advantage in attending four-year college is almost double after college expansion. Guo and Wu (2008) also demonstrate an increase in the impact of social background on college attendance, with the help of data from the China Health and Nutrition Survey (CHNS). A recent study by Jiang and Tam (2015) finds that students from better educated families have an increased advantage in higher education attendance, while higher education opportunities for students from less educated families are depressed during higher education expansion.

However, Li (2010) compares the effect of family socio-economic status before and after college expansion and finds that the educational inequality based on family background remains stable. There have been international and comparative studies examining how the rapid expansion of higher education has resulted in a growing number of families and students grappling with the uncertainty of employment after graduation (Quinn and Kay 2007; Kong and Sreng 2012), especially when international reputable reviews publish articles along the lines of The Economist's 'The world is going to university: 
more and more money is being spent on higher education. Too little is known about whether it is worth it.' (The Economist, 28 March 2015).

Putting the previous studies into perspective, whether educational inequality persists or not is still controversial. In addition, studies of educational inequality in China are handicapped by design flaws that the authors assumed a dichotomy variation (instead of a continuous trend) of the inequality before and after higher education expansion (e.g., Li 2010; Yang 2006; Liu 2006). And the findings based on the data of early years only present the changes of inequality after expansion for a short period of time. Therefore, the overall time trend of inequality in higher education admission, especially a recent cohort trend, remains unknown. In this chapter, we employed recent nationally representative data to examine the cohort trend of the inequality in higher education admissions.

\subsection{The rising importance of a family's educational and economic resources}

The analysis begins with a standard binary logit model of college attendance. The change of class inequality is measured by the extent to which the effects of socioeconomic origin vary across entry cohorts, which is reflected in an interaction effect of socio-economic origin and cohort. Table 1 compares two dimensions of class inequality - the effects of socio-economic origin on the respondents' higher education attendance adjusting for gender and hukou origin.

Model 1 indicates that a father's education, SEl and hukou origin strongly predict a respondent's college attendance. A respondent from a better educated, more wealthy family, and/or urban hukou origin is more likely to enter higher education. Moreover, the cohort variable is also positively significant at .05 significance level, suggesting that the overall higher education attendance has been increasing over time. However, the overall increase in higher education opportunties does not mean that the new opportunities would be equally distributed.

Models 2-3 examine the cohort trend of a father's education and SEI effect on higher education attendance, respectively: the interaction between a father's education/SEI and higher education admission cohort. The results show that both a father's education and SEI effect increase across cohorts, suggesting a rising class inequality in higher education attendance. This result is largely consistent with previous studies (e.g., Yang 2006; Liu 2006). 
Table 1 Logit models of college attendance: cohort trend of two dimensions of class inequality $(N=4,604)$

\begin{tabular}{lccc}
\hline & Model 1 & Model 2 & Model 3 \\
\hline Family Background & & & \\
Father's education & $2.816^{* * *}$ & $1.725^{* * *}$ & $2.863^{* * *}$ \\
& $(0.338)$ & $(0.514)$ & $(0.338)$ \\
Father's SEI & $0.565^{*}$ & $0.571^{*}$ & 0.015 \\
& $(0.247)$ & $(0.249)$ & $(0.410)$ \\
Hukou origin & $1.302^{* * *}$ & $1.299^{* * *}$ & $1.305^{* * *}$ \\
$\quad(1=$ urban) & $(0.112)$ & $(0.112)$ & $(0.112)$ \\
Trends of Class Inequality & & & \\
Father's education $\times$ Cohort & & $1.611^{* *}$ & \\
& & $(0.544)$ & \\
Father's SEI × Cohort & & & $0.691+$ \\
& & & $(0.404)$ \\
Basic Controls & & & \\
Cohort & $0.321^{* * *}$ & -0.420 & 0.126 \\
& $(0.097)$ & $(0.265)$ & $(0.144)$ \\
Gender & -0.060 & -0.066 & -0.063 \\
(1= female) & $(0.101)$ & $(0.102)$ & $(0.102)$ \\
Constant & $-3.671^{* * *}$ & $-3.197^{* * *}$ & $-3.538^{* * *}$ \\
& $(0.185)$ & $(0.247)$ & $(0.203)$ \\
Pseudo R-squared & 0.172 & 0.174 & 0.173 \\
\hline
\end{tabular}

Source: Chinese General Social Survey 2006 and 2008.

Note: Robust standard errors in parentheses

${ }^{* * *} p<0.001,{ }^{* *} p<0.01,{ }^{*} p<0.05$

Figure 3 presents a scatter plot of the estimated effects of a father's education on college attendance from a logistic regression model. Each dot is an estimated effect of a father's education on college attendance for a specific higher education admission year. The nonlinear curve is the estimated trend of a father's education effect by Locally Weighted Scatterplot Smoothing (LOWESS). What is particularly intriguing is the dramatic surge in the father's education effect in higher education attendance after the big bang of China's higher education since 1998. This figure supports our regression model findings that there is an increase in the importance of a family's educational resource (cultural capital) in determining a child's higher education attendance amid higher education expansion. 
Figure 3 Cohort trend of a father's education effect on higher education attendance

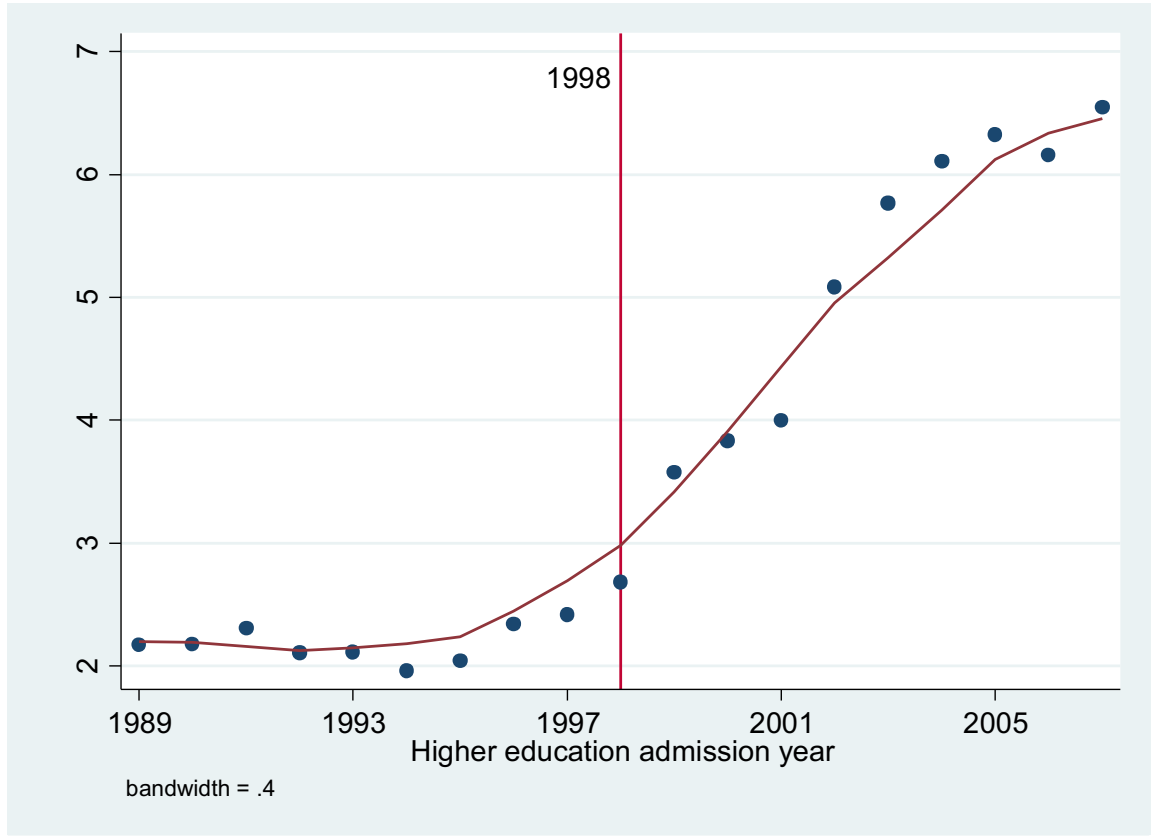

Source: Chinese General Social Survey 2006 and 2008.

Note: Each dot is an estimated effect of a father's education on college attendance for a specific higher education admission year according to a logistic regression model, and is taken as a simple moving average of order seven. In addition to the interactions between a father's education and higher education admission year, the logistic regression model also controls for gender, urban origin, and a father's SEI. The nonlinear curve is estimated by a Kernel-weighted local polynomial smoothing procedure with a degree of 0.4 .

In Figure 4, we use a similar method of presenting a scatter plot of the estimate effects of a father's SEI effect on higher education attendance. The importance of a family's economic resource (measured by a father's SEI) in determining higher education attendance also increased over time, but the year of uptake is 2001, which is later than the year of uptake for higher education expansion, which occurred in 1998. Our interpretation of this 'time-lag' of a father's SEl effect is the late development of shadow education. For the higher education admission cohorts before 2000, there were limited market alternatives to direct parental involvement in a student's homework assignments and lesson reviews. Thus, the competitive advantage of families in advancing a student's academic performance often manifested as the engagement of parents in the learning activities of students. Wealthy families did not usually have any compensation for educational resource. However, there has been an increase in private tutorials in recent years, which could help students in academic learning as long as their family can 
afford to pay (Zhang 2014). As such, a family's economic resources and family assets become a competitive advantage in enhancing a student's academic performance. The parental economic resource is likely to be a source of competitive advantage for higher education attendance in more recent years.

Figure 4 Cohort trend of a father's SEl effect on higher education attendance

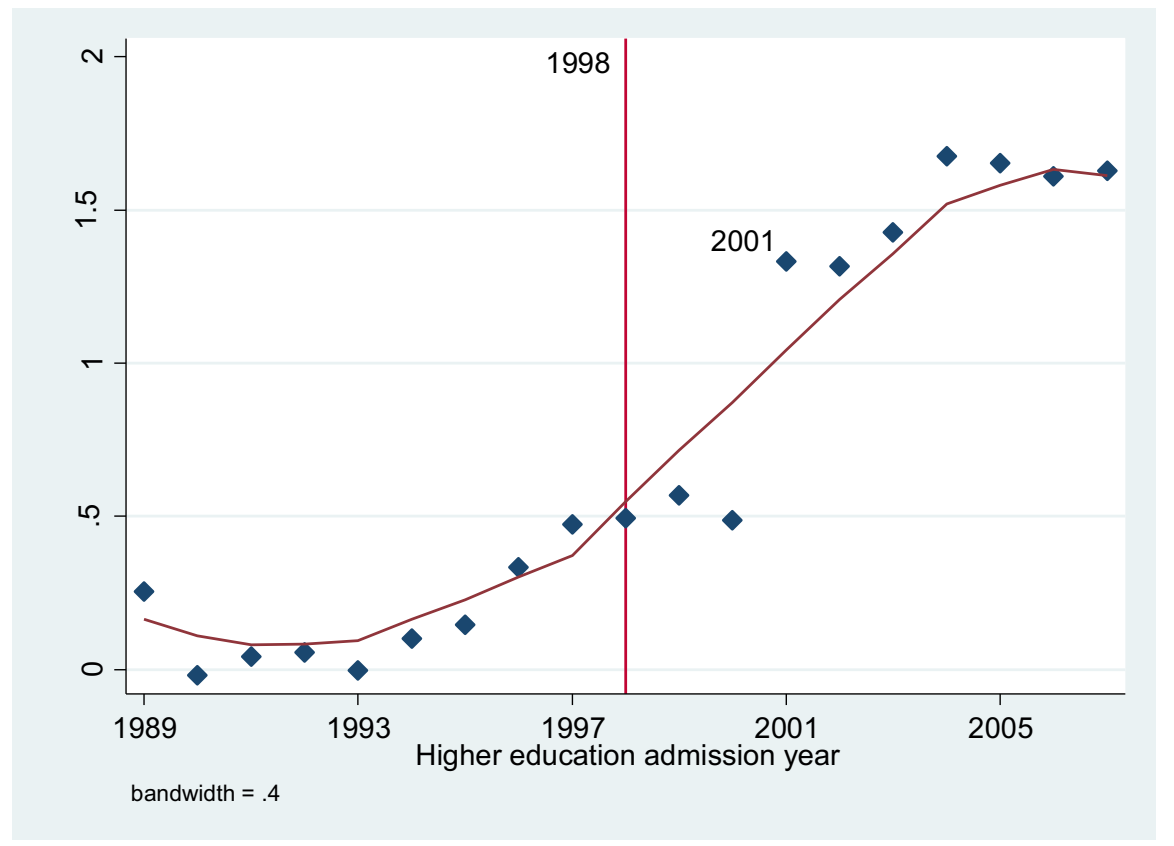

Source: Chinese General Social Survey 2006 and 2008.

Note: Each dot is an estimated effect of a father's socio-economic index (SEI) on college attendance for a specific higher education admission year according to a logistic regression model, is taken a simple moving average of order seven. In addition to the interactions between a father's SEI and higher education admission year, the logistic regression model also controls for gender, urban origin, and father's education. The nonlinear curve is estimated by a Kernel-weighted local polynomial smoothing procedure with a degree of 0.4 .

\subsection{Explanations: positional values or labour market incentive}

After decades of empirical research on the generality of the persistent inequality of educational opportunity, Alon (2009) recently established a new theoretical model of higher education inequality. She incorporated class adaptation (investment in competitive success) and organisational exclusion (the importance of admission barriers) as twin mechanisms mediating the family background effect on college destinations. Both mechanisms are depicted in the context of a meritocratic pathway; 
recent studies (Tam and Jiang 2014, 2015) extend the model by incorporating meritocratic and non-meritocratic pathways. In addition, Alon (2009) emphasises the role of competition for higher education admission - the balance of supply and demand for college places - as a means of interpreting the evolution of educational inequality in a society. She uses the competition model to explain the variation in educational inequality in the United States within a relatively short period of time. When the competition for college declined from 1972-82, inequality in college attendance decreased. When the college competition intensified during the 1982-92 period, inequality rose.

We apply Alon's theoretical model to interpret China's rising educational inequality in higher education attendance. This model implies that inequality in higher education attendance can increase amid expansion if competition for higher education is intensified. In fact, the 'positional deflation' argument suggests that competition could increase amid higher education expansion. This is because the positional value of the qualifications of upper secondary education and higher education decrease during higher education expansion. This argument builds on the idea that education functions as 'a positional good' (Hirsch 1976; Sørensen 1979). The value of an educational credential is determined by its relative ranking in the hierarchy of educational credentials. To the extent that education is a positional good, higher education expansion decreases the value of upper secondary education, and even the value of higher education.

This deflation of educational credential would motivate more students to invest more to enter higher education (Van de Werfhorst 2009). The competition for higher education is thus further intensified. As society's upper classes usually have advantages in academic performance, the intensified competition for admissions enlarges the class difference in those entering higher education. The reproduction of social inequality through the process of education - where inter-generational transfer is made possible for those who come from the middle classes and above, and enjoy far more social and cultural capital - has unquestionably influenced people's decisions when choosing a university education, in terms of their rational calculation of risks and uncertainty critical to individual life courses (Furlong and Cartmel 2009; Giddens 1991; Zinn 2004, 2008).

However, Jiang and Tam (2015) find that it is not the expansion of education but the labour market incentive that drove competition within higher education, and subsequently increased class inequality in higher education attendance. Their study posits the 'labour market incentive explanation': that the balance of labour market supply and demand of college graduates (reflected in the earnings premium for college graduates over upper secondary education graduates) determines the competition in winning a place at university. Labour markets induce individual behavioral responses so that family investment in education meets the demand for graduates by employers. 
Labour economists have a longstanding interest in the evolution of the supply and demand of higher education (such as Goldin and Katz 2008; Acemoglu and Autor 2012). Individuals respond systematically to labour market incentives, and the college premium provides the price signal needed to coordinate the supply and demand of college graduates. When relative supply is low (equivalently, when relative demand is high), the college earnings premium increases to induce a growth in supply of college graduates (Jiang and Tam 2015). This explanation is consistent with the human capital investment theory whereby education is regarded as an investment in human capital (Becker 1993). The expectation of higher returns in the future stimulates current demand for education (Checchi 2006: 19-23).

Therefore, the labour market incentive explanation underscores the college earnings premium as the main driver of the demand for higher education admission, which is reflected in the competition among potential applicants in competing for a college place. The college premium thus triggers an increase in class-differentiated educational investment ${ }^{7}$ to secure college places, further enlarging class inequality in higher education admission.

Figure 5 (page 14) presents the trend of the national earnings premium of higher education. The figure is drawn on the statistics from Jiang and Tam (2015). We expanded the estimates of the premium for more recent cohorts (see Jiang and Tam 2015 for details of the measures). Comparing this trend with the trend of a father's education effect on higher education attendance (Figure 3), we find that both trends display the same striking uptake for the admission cohort of 1998. The matched cohort trends strongly suggest that the labour market incentive can account for the rising class inequality in higher education attendance during the higher education admission cohorts of 1989-2007 in China.

Earnings premiums for higher education graduates over upper secondary education graduates increase over time during the higher education admission cohorts of our study 1989-2007. However, the absolute earnings for more recent college graduates may not always increase (they may become stable or even decrease); the labour market conditions may change in the post-expansion period. More importantly, an increase in opportunities for higher education and earnings premium for college graduates does not mean more equal opportunities in the labour market or more equal opportunities for college graduates in finding jobs. In contrast, higher education expansion may have negative impacts on the labour market. In the next section we will discuss the declining opportunity in graduate employment during higher education expansion.

\footnotetext{
${ }^{7}$ The upper classes usually have more resource for investing in their offspring's education; the educational investment is thus class-differentiated.
} 
Figure 5 National earnings premium of higher education graduates

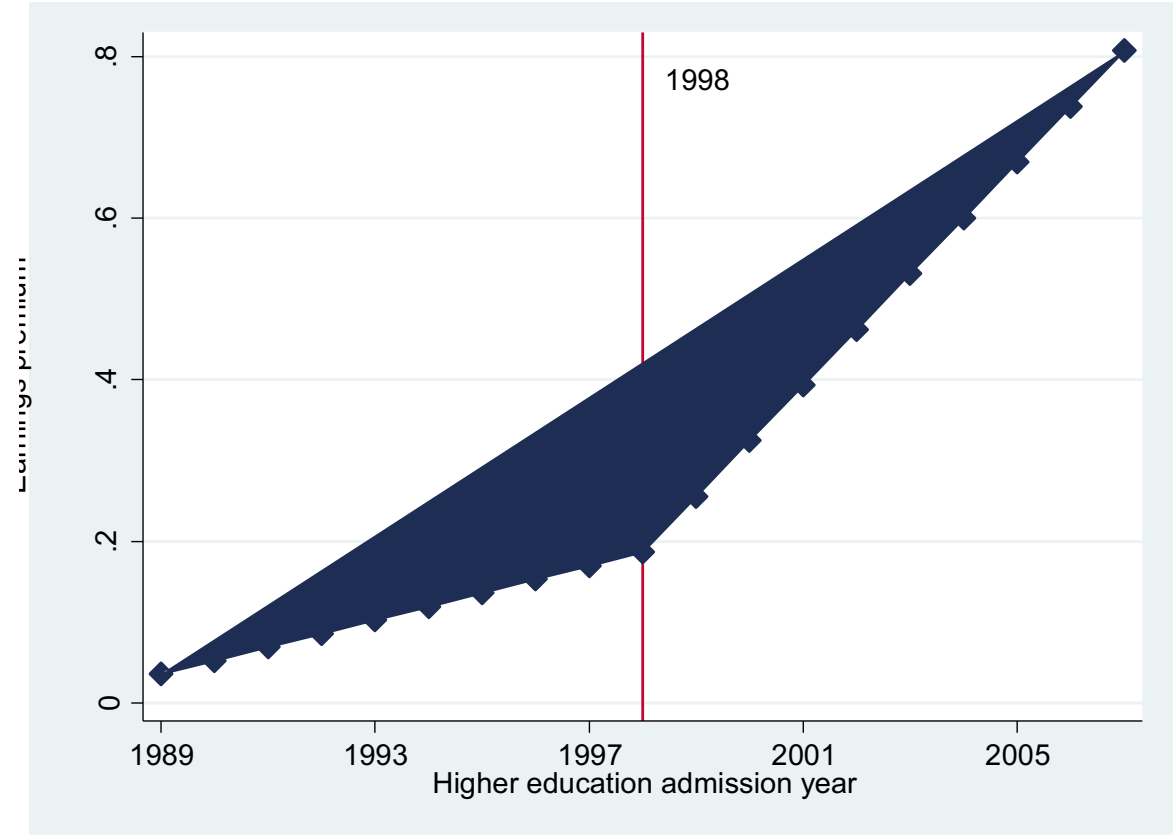

Note: The earnings premium was presumed to be observed by an individual when he/she was age 15 . The higher education admission year is the year when this individual was presumed to enter higher education. Earnings premium is estimated from the Chinese Household Income Project 1988, 1995 and 2002. The reference lines display the same uptake cohort for the trends of educational inequality. See Jiang and Tam (2015) for detailed discussion of the measures of the earnings premium.

\section{Declining opportunity in graduate employment}

\subsection{Unemployment}

As higher education has experienced explosive growth for several years, early cohorts of college graduates caught up in this tidal wave of expansion are expected to enter the labour market, and lead to a substantial growth in the supply of college-educated workers. Whether and how the expansion affects labour market and graduate employment are important to understand. Recent studies suggest that graduates in Europe, North America and East Asia have been negatively affected in terms of employment and social mobility by the rapid expansion of higher education. As Lauder rightly points out, around 40-50 per cent of college graduates in the USA are doing subgraduate work; about 52 per cent of four-year college graduates are in jobs that match their skills, whereas 48 per cent are overqualified for the work they do (Vedder et al., cited in Lauder 2014). The situation is similar in Britain; the Office for National Statistics 
reports that underemployment among graduates rose from 37 per cent in 2001 to 47 per cent in June 2013 (Lauder 2014).

Comparing the massification of higher education and its impact on graduate employment and social mobility, Green and Mok (2013) identify similar developments in Europe and Asia. Pointing to the growing number of unemployed college graduates in the context of intensified competition for positions among youth in the globalising economy, Robertson and Dale (2013) challenge the conventional wisdom that higher education provides young people with better career prospects and upward social mobility. Worse still, many of these college graduates have borrowed money for their higher education, believing that they would have better career prospects after graduation. However, international research on youth employment in general, and college graduate employment in particular, has clearly shown that highly educated people are not guaranteed better job opportunities (Brown, Lauder and Ashton 2011; Robertson and Dale 2013; Mok and Neubauer 2016).

Figure 6 National employment rate, numbers of graduates and unemployment

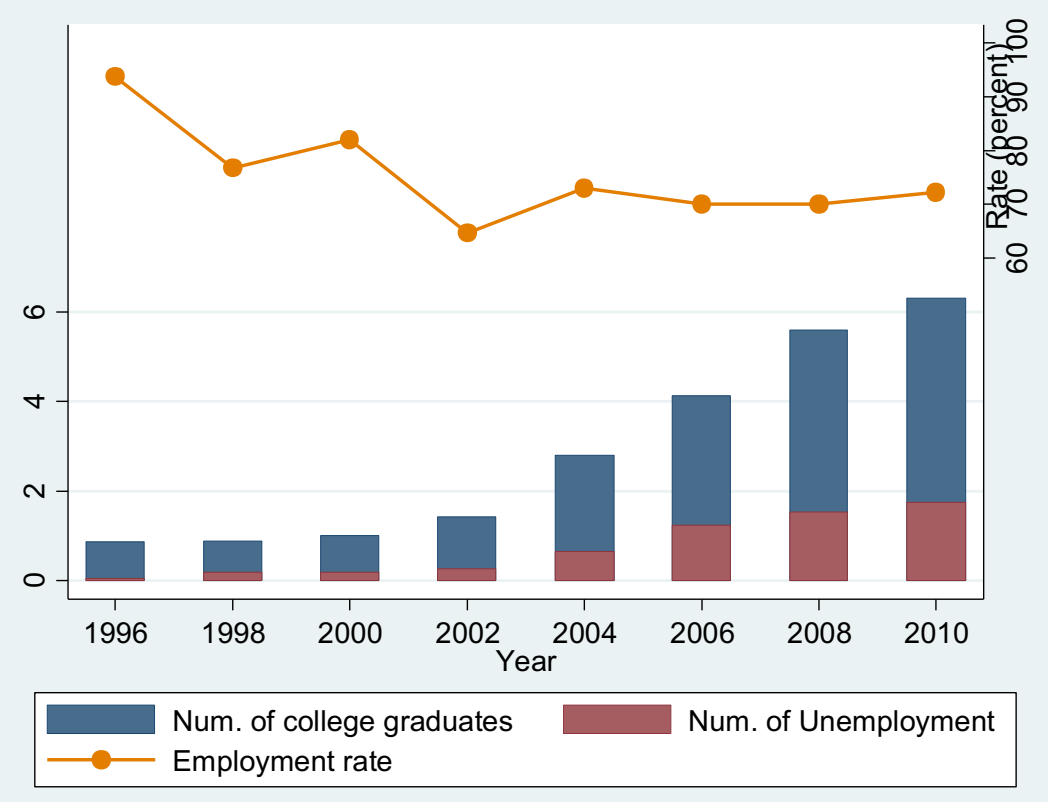

Source: China Labour Statistical Yearbook, 1996-2010.

China's higher education expansion brings similar challenges for employment. Figure 6 presents the changes of labour market conditions from 1996-2010. Since 2002, college graduates who experienced rapid higher education expansion entered the labour market; the numbers of higher education graduates dramatically increased. Meanwhile, unemployment also increased, and the overall trend was for the employment rate to 
decrease. The matched time trends imply that expansion may result in unemployment in the labour market.

Figure 7 The ratios of four-year and junior college graduates that never work to overall unemployed college graduates

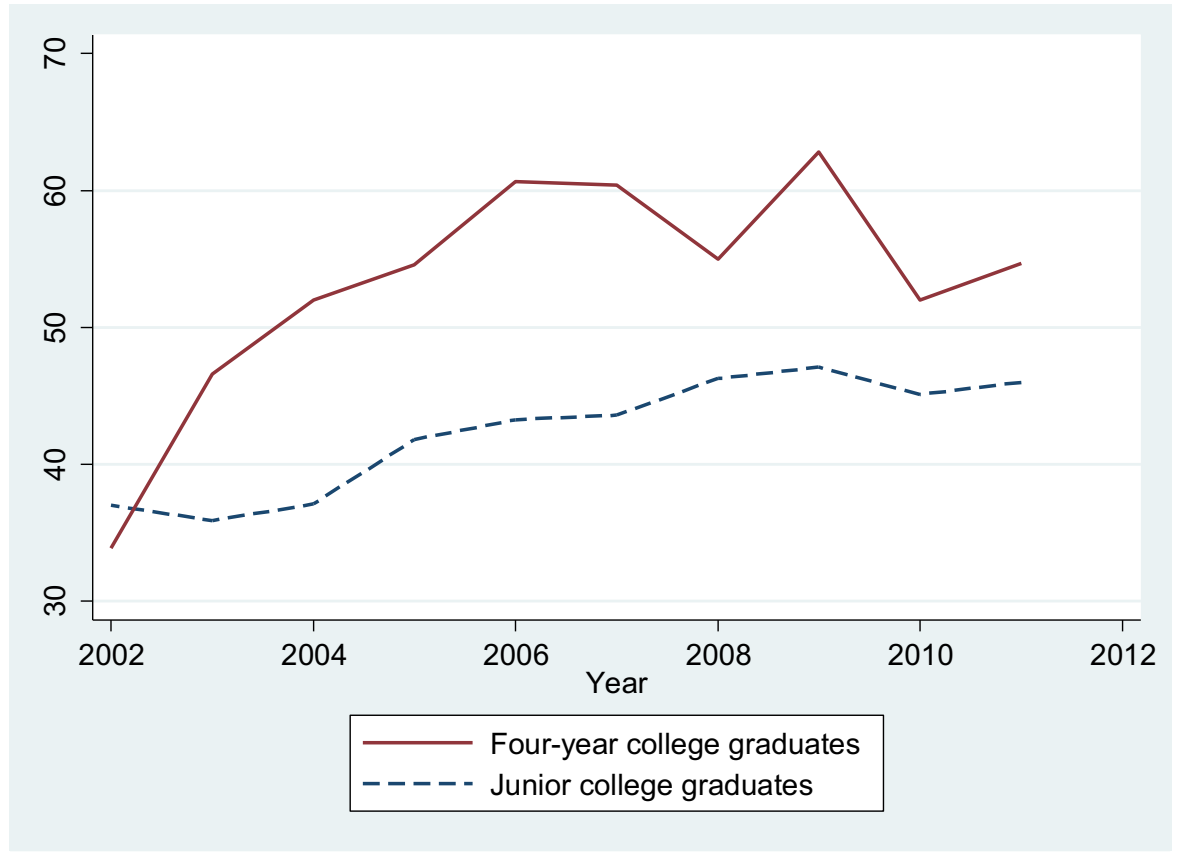

Source: China Labour Statistical Yearbook, 2003-2012.

Higher education expansion may not only affect overall unemployment, it may also have a direct impact on college graduates' employment prospects. According to official statistics, the ratio of university and junior college graduates that never work, compared to overall unemployed college graduates, has increased since 2002 (Figure 7), when the college graduates who were caught up in expansion started entering the labour market. This means that an increasing proportion of unemployed college graduates have been unemployed since graduating. In addition, this proportion was over 50 per cent for four-year college graduates since 2003, and 40 per cent for junior graduates since 2005 . The finding casts doubt on the idea that higher education brings greater advantages in the labour market and a higher return. It also suggests that higher education expansion may not create more opportunities and upward mobility in the labour market. 


\subsection{Stagnation in social mobility}

For decades, human capital theory dominated the explanation of returns to investment in education (Becker 1962, 1993; Becker and Chiswick 1966; Mincer 1974;

Psacharopoulos 1973, 1985; Schultz 1961). The theory suggests that the level of education received is positively correlated with earnings. A person completing a fouryear degree or who has a three- or two-year college education can in principle enjoy a greater advantage in the labour market and thereafter a higher real income in his or her later life (Psacharoloulos 1994; Psacharopoulos and Patrinos 2004). In this regard, college graduates enjoy more chances for upward occupational and social mobility, as education plays a crucial role in social mobility.

Nonetheless, some scholars argue that the most important determinants of income and social mobility are not education-related factors, but family background. They argue that family background provides educational opportunities, competitiveness in the labour market, occupational and social mobility and so forth (Dale 2015; Brown et al. 2011). In the 1960s, a study using a large-scale questionnaire survey of 4,000 public schools and more than 645,000 pupils found that family background has the strongest relation to educational achievement, and parents' education has the strongest relation for nearly all groups, whereas the characteristics of schools and teachers have weak relations (Coleman et al., 1966). Recently, the relationship between social mobility and university credentials has also been challenged in both developed and emerging economies. Haveman and Smeeding's (2006) research reveals a growing income-related gap both in access to, and success in, higher education in the United States. In top-tier colleges and universities, almost three-quarters of the entering classes are from the highest socio-economic quartile. The pool of qualified youth is far greater than the number admitted and enrolled. These studies challenge the conventional wisdom that education is one of the most important determinants of labour market success. It is particularly unclear whether graduating from university leads to promising career prospects and eventually to upward social mobility.

Wen's study (2005) is a recent and influential piece of research into China's higher education expansion and graduate employment. The study, based on a large-scale questionnaire survey, found that family background plays a crucial role in graduates' employment in the labour market: 'the better the family background, the more opportunities to find a job, to pursue further study, and the higher the starting salary'. However, this study was conducted in 2003 - in an early period of higher education expansion. It is unclear whether the situation remains true in the post-expansion period. In this section, we examine whether family background and social resource still exert strong influences on employment, and how college graduates perceive social mobility in the post-massification of higher education period. 
Similar observations are found in recent research by Wen and Ngok (2011) who discover a growing number of college graduates are becoming increasingly dissatisfied with their employment, especially those graduates who have come from rural areas, enrolling in university education in major cities. Conducting intensive interviews with these unhappy graduates who live together in cities under unfavourable living conditions, receive only basic salaries, and - lacking citizenship in the urban area have no welfare entitlement, Wen and Ngok found a special group who they term the 'new poor' or 'new working poor' emerging in China (2011). The interviews reported in their study have clearly demonstrated how the expansion of higher education has inevitably turned some new college graduates from 'welfare poor' to 'working poor'. Wen and Ngok (2011) suggest that if higher education expansion does not match the changing market needs, new graduates may encounter an unacceptable social and economic environment during their transition from university student life to adult working life. What makes this group of new graduates unhappy is that they have invested financially heavily in obtaining a university degree, but have found themselves less socially respected, and also economically disadvantaged. As a result, many of them have begun to criticise the marketisation of higher education and complain about the poor teaching quality and learning experience that they received. A strong sense of feeling cheated during the process of university education has led to a growing anger among these new graduates suffering from less favourable employment conditions (Wen and Ngok 2011) than in the past.

In sum, prior studies suggest that family background plays an important role in employment and social mobility for individuals. Even for college graduates who may enjoy more advantages than those without college degrees, their family background may still have a great impact on their opportunities in the labour market. We suggest in this study that the importance of family background on employment persists and even increases amid the massification of higher education. In the following sections, we discuss our findings on the impact of family background on employment, in terms of subjective perception and objective reality amid college expansion.

\subsection{The importance of family background on employment: subjective perception}

To understand how college students perceive social stratification and social opportunity/ mobility during the recent period of higher education massification, the youth survey was conducted at six different colleges/universities in Guangzhou. The students were asked about perceived social opportunities, in particular the factors affecting social mobility, the impact of parents' social status, how they are preparing for social mobility after graduation, and how they evaluate government policies. 
According to the survey results, students regarded family background as playing a substantial role in college students' employment and future development; 79.4 per cent of the respondents said that family background and resources have a great impact on the employment of college students. Similarly, as shown in Figure 8, 76 per cent of respondents agreed that family background and social resources affect their future development. Among the respondents, 25 per cent thought that family background and social resources have a strong influence, while 51.4 per cent believed a relatively strong influence, and 17.4 per cent believed some influence. Only seven per cent of respondents said that family background and resource have a small, or hardly any, influence on their future development.

Figure 8 Perception of the influence of family background and resource on a person's future development, Guangzhou

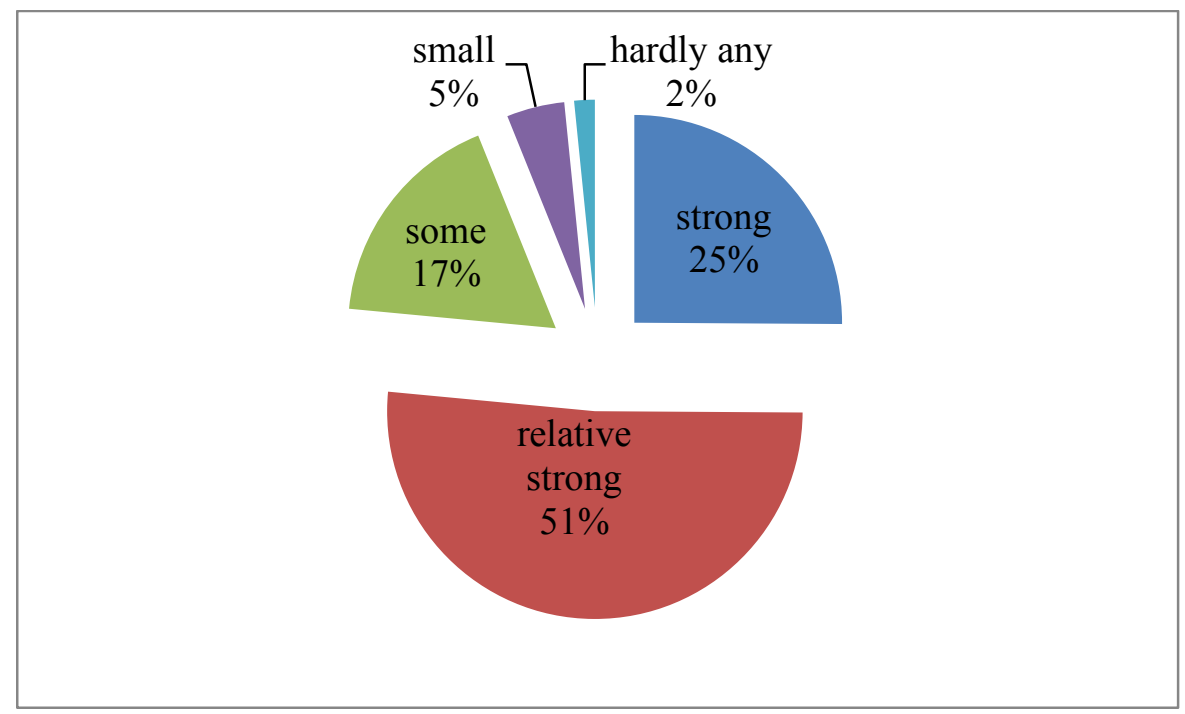

Source: Youth survey of graduate employment and social mobility in Greater China.

Note: The survey question is: 'Do you think family background and resource have any influence on one's future development?'

\subsection{The importance of family background on employment: objective reality}

We also use a recent nationally representative social survey - the Chinese General Social Survey - to examine whether family background and social resource play an important role in employment during higher education massification. Table 2 (page 20) compares different sources of help for respondents in getting their first jobs, before and after higher education expansion. The results show that a substantial proportion of all 
respondents, including college graduates, gained help from family or non-family networks. The findings echo early research about the importance of social networks in seeking jobs (e.g., Granovette 1973, 1974; Lin, Ensel and Vaughn 1981; Bian and Ang 1997). Compared with the period before expansion (1991-2002), respondents entering the labour market after expansion are more likely to seek help in attaining their first jobs. The percentage of those gaining help in procuring employment increased for all respondents, including college graduates. In particular, the percentage of college graduates gaining family help increased more than 80 per cent (from 10.6 per cent to 18.72 per cent).

The results suggest that when the competition increased in the labour market after college expansion, family background appears to become more important in helping individuals in their employment. In addition, holding a college degree does not change the fact that family background and social resource became increasingly crucial in individuals' employment during higher education massification. This trend of the growing importance of social networks in finding jobs may correlate to the intensified competition in the labour market amid the massification of higher education. While increasing numbers of college graduates who experienced higher education expansion look for jobs, candidates from all educational levels are more likely to try all means to enhance their competitive advantage in the labour market. Social capital is an important means by which to gain access to information and resource in the labour market.

Table 2 The main source of help in getting a first job: comparing all respondents and college graduates before and after college expansion (in percentages)

\begin{tabular}{lllll}
\hline \multirow{2}{*}{$\begin{array}{l}\text { The main source of } \\
\text { help }\end{array}$} & $1991-2002$ & & $2003-2008$ & \\
\cline { 2 - 5 } & $\begin{array}{l}\text { All } \\
\text { respondents }\end{array}$ & $\begin{array}{l}\text { College } \\
\text { graduates }\end{array}$ & $\begin{array}{l}\text { All } \\
\text { respondents }\end{array}$ & $\begin{array}{l}\text { College } \\
\text { graduates }\end{array}$ \\
\hline Family & 16.22 & $\mathbf{1 0 . 6}$ & 17.8 & $\mathbf{1 8 . 7 2}$ \\
\hline Non-family & 26.46 & $\mathbf{1 2 . 4 9}$ & 28.03 & $\mathbf{1 4 . 8 3}$ \\
\hline None & $\mathbf{5 7 . 3 3}$ & 76.91 & $\mathbf{5 4 . 1 7}$ & 66.44 \\
\hline Total & $100 \%$ & $100 \%$ & $100 \%$ & $100 \%$ \\
\hline
\end{tabular}

Source: Chinese General Social Survey 2008.

Note: Non-family help includes the help from friends, acquaintances, classmates, comrades, and others. The sample sizes for all respondents and college graduates are 1445 and 490 respectively. 
Table 3 What kind of non-family help in getting a first job: comparing all respondents and college graduates before and after college expansion (in percentages).

\begin{tabular}{lcccc}
\hline $\begin{array}{l}\text { What Kind of Non-Family } \\
\text { Help }\end{array}$ & $\begin{array}{l}\text { 1991-2002 } \\
\text { All }\end{array}$ & $\begin{array}{l}\text { College } \\
\text { respondents }\end{array}$ & $\begin{array}{l}\text { All } \\
\text { graduates }\end{array}$ & $\begin{array}{l}\text { respondents } \\
\text { graduates }\end{array}$ \\
\hline $\begin{array}{l}\text { Provide job information } \\
\begin{array}{l}\text { Help preparing application } \\
\text { materials }\end{array}\end{array}$ & 64.71 & 42.72 & $\mathbf{7 2 . 7 9}$ & 69.48 \\
\hline $\begin{array}{l}\text { Help submitting application } \\
\text { materials }\end{array}$ & 2.89 & 13.08 & 5.38 & 3.47 \\
\hline $\begin{array}{l}\text { Arrange to meet the } \\
\text { employer's agent }\end{array}$ & 16.25 & 12.68 & 4.03 & 10.50 \\
\hline $\begin{array}{l}\text { Do a favour for the employer } \\
\text { Others }\end{array}$ & 2.26 & 9.18 & 17.02 & 12.55 \\
\hline Total & 5.63 & 20.43 & 0 & 0 \\
\hline
\end{tabular}

See Table 2 for source and notes.

We go one step further to examine what particular kind of help from non-family (Table 3 ) and family (Table 4) enable individuals to get a job. It is worth noting that the majority of the non-family and family help is to provide job information. In particular, more than 60 per cent of help from non-family networks during the period 2003 to 2008 involves providing job information. And the percentages for all respondents and college graduates have increased in the massification period. This is an interesting phenomenon. While various information about jobs is publicly available nowadays, and we can easily find information from traditional (print) and new (internet) media, there are still some individuals who obtain their jobs through internal job information from their networks. This suggests that effective information about jobs may not be fully transparent and inclusive, but may be exclusively available to individuals from socially advantaged families.

In addition, Table 4 (page 22) indicates that for college graduates, there is an increase in the percentage of family helping with submitting application materials and arranging meetings with the employers' agents. This means that college graduates' families adopted a more aggressive means of helping their offspring in getting jobs than before. Instead of simply providing job information, families of college graduates became involved in direct interactions in the recruitment process during the massification of higher education. 
Table 4 What kind of family help in getting a first job: comparing all respondents and college graduates before and after college expansion (in percentages).

\begin{tabular}{|c|c|c|c|c|}
\hline \multirow[b]{2}{*}{ What Kind of Family Help } & \multicolumn{2}{|l|}{$1991-2002$} & \multicolumn{2}{|l|}{$2003-2008$} \\
\hline & $\begin{array}{l}\text { All } \\
\text { respondents }\end{array}$ & $\begin{array}{l}\text { College } \\
\text { graduates }\end{array}$ & $\begin{array}{l}\text { All } \\
\text { respondents }\end{array}$ & $\begin{array}{l}\text { College } \\
\text { graduates }\end{array}$ \\
\hline Provide job information & 55.51 & 62.74 & 67.16 & 45.70 \\
\hline $\begin{array}{l}\text { Help preparing application } \\
\text { materials }\end{array}$ & 6.94 & 14.69 & 5.47 & 13.05 \\
\hline $\begin{array}{l}\text { Help submitting application } \\
\text { materials }\end{array}$ & 9.81 & 4.11 & 3.45 & 8.03 \\
\hline $\begin{array}{l}\text { Arrange to meet the } \\
\text { employer's agent }\end{array}$ & 18.63 & 10.54 & 19.99 & 31.04 \\
\hline Do a favour for the employer & 3.54 & 7.91 & 3.07 & 2.17 \\
\hline Others & 5.58 & 0 & 0.86 & 0 \\
\hline Total & $100 \%$ & $100 \%$ & $100 \%$ & $100 \%$ \\
\hline
\end{tabular}

See Table 2 for source and notes.

In short, family background and social resources are not only perceived as crucial determinants in the future development of college students, but also play an important role in an individual's employment. Most importantly, the significance of family background and social resources in social mobility does not decrease amid massification of higher education. Instead, more families - especially families of college graduates - tend to mobilise social resources to help their offspring find jobs. We suggest this is interpretable, as massification of higher education increases the supply of college-educated workers, the competition of the labour market would intensify (especially when the demand of college-educated workers does not catch up with the supply). Individuals would mobilise all available resource to secure their job positions. Families with better social resources tend to have advantages in helping their offspring win the competition of the labour market (Dale 2015; Brown et al. 2011).

\subsection{Youth expectations of social mobility}

Our analyses above clearly show that family background plays an important role in graduate employment amid the massification of higher education. College graduates, especially those who do not have efficient social capital from family and non-family networks, may seriously suffer from the difficulties in finding jobs amid massification of higher education. In fact, our survey shows that quite a few college students were pessimistic about their future upward social mobility, although they had not yet entered the labour market (Figure 9). In the same youth survey in Guangzhou mentioned earlier, 
when asked whether the opportunities for upward social mobility among college students were decreasing, more than 50 per cent strongly agreed or agreed with this argument (14 per cent of respondents strongly agreed, 40 per cent agreed). 32 per cent held a neutral opinion, and only 14 per cent strongly disagreed or disagreed. It is obvious that most college students tended to doubt their future social mobility, even with a college degree.

Figure 9 College students' perception of upward social mobility, Guangzhou

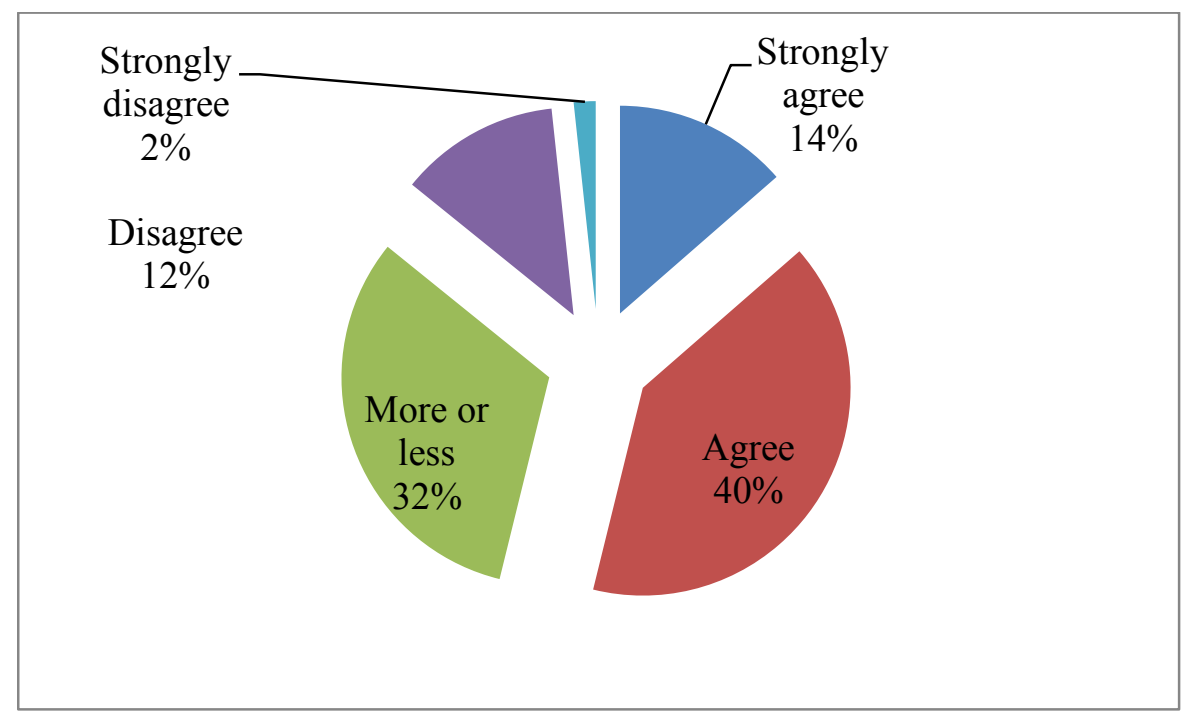

Source: Youth Survey of Graduate Employment and Social Mobility in Greater China.

\section{Discussion and conclusion: reconstructing new education governance frameworks in promoting education equality}

Our above analysis clearly suggests the massification of higher education and the mismatch between the supply of college graduates and the changing labour market needs have inevitably led to unfavorable graduate employment confronting China today. Human capital theory predicts that, other things being equal, raising participating in higher education will initially increase inequality, as rates of return rise, then decrease it as expansion reaches mass levels and rates of return decline. Providing the output of graduates outpaces the demand for graduate skills (which appears to be the case in many countries now), supply and demand pressures reduce the pay premium for degrees and lower income inequalities (Knight and Sabot 1987). But our present research suggests a different scenario emerging when higher education has been affected by the strong tide of privatisation and marketisation, where individuals and families have to take up significant financial responsibility to go to university. 
Our study has shown that under some circumstances higher education expansion (at mass level) may actually increase inequality, particularly when inter-generational transfer of assets and resources - not necessarily in monetary terms but encompassing other forms of support like social and cultural capital - have affected higher education admissions, prospective job opportunities and, eventually, upward social mobility (Green and Mok 2013; Mok and Wu 2016; Lauder 2014). Seen in this light, the expansion of higher education may not promote fairness but may instead intensify educational inequality - as our present study demonstrates.

Most important of all, the present research points out the limitations of existing approaches when analysing the distributive function served by education. Most approaches to social justice in and through higher education are based on common sense notions of social justice, which typically assume a distributive framework that not only ignores, but more importantly hides and disguises critical institutional analysis of domination and oppression.

This dominant distributive paradigm defines social justice as the morally proper distribution of social benefits and burdens among society's members. Our above study offers strong empirical evidence to challenge this conventional wisdom, especially when education has failed to serve such a distributive function. In particular, when higher education is seen as a private good and social justice is generated and maintained through particular forms of social relations, as they are experienced in the valorisation of higher education knowledge (Dale 2015).

To break away from the existing education, governance frameworks structurally and strategically select particular interests which in turn distribute (more or less unequal) social opportunities and outcomes (and therefore the basic structure). We need to reconstruct a new education governance to promote educational equality, because the existing education governance frameworks place responsibilities on those who are particularly advantaged by them (societal interests). In order to break from the existing unequally, but stubbornly imposed, social order, we need to create new modes of accountability and spaces for representation (politics) within and beyond the national state to protect those in less advantaged positions or those who are being socially and economically exploited (Robertson and Dale 2013). 


\section{References}

Acemoglu, D. \& Autor, D. (2012). What does human capital do? A review of Goldin and Katz's the race between education and technology. Journal of Economic Literature 50(2), 426-63.

Alon, S. (2009). The evolution of class inequality in higher education competition, exclusion, and adaptation. American Sociological Review, 74(5), 731-755.

Becker, G. S. (1962). Investment in human capital: A theoretical analysis. The Journal of Political Economy, 70(5), 9-49.

Becker, G. S. (1993). Human capital: A theoretical and empirical analysis, with special reference to education (third ed.). Chicago: The University of Chicago Press.

Becker, G. S., \& Chiswick, B. R. (1966). Education and the distribution of earnings. The American Economic Review, 56(1/2), 358-69.

Bian, Y., \& Ang, S. (1997). Guanxi networks and job mobility in China and Singapore. Social Forces, 75(3), 981-1005.

Bian, Y., \& Li, L. (2012). The Chinese General Social Survey (2003-8). Chinese Sociological Review, 45(1), 70-97.

Brown, P., Lauder, H., \& Ashton, D. (2011). The global auction: The broken promises of education, jobs, and incomes. New York: Oxford University Press.

China Labor Statistical Yearbook. (1996-2012). Beijing: China Statistical Press.

Checchi, D. (2006). The economics of education: Human capital, family background and inequality. New York: Cambridge University Press.

Educational Statistics Yearbook of China, (1982-2012). Beijing: China Statistical Press.

Deng, Z., \& Treiman, D. J. (1997). The impact of the cultural revolution on trends in educational attainment in the People's Republic of China. American Journal of Sociology, 103(2), 391-428.

Coleman, J. S., et al. (1966). Equality of educational opportunity (third ed.). Salem: New Hampshire. 
Dale, R. (2015). Employability and mobility in valorization of higher education qualifications. Paper presented at the International Symposium on Globalization, Changing Labout Market and Social Mobility: Challenges for Education and Urban Governance, 20 January 2015, Hong Kong Institute of Education.

Educational Statistics Yearbook of China, 1982-2012 (annual). Beijing: China Statistical Press.

Economist. (2015, March 28). The world is going to University: More and more money is being spent on higher education. Too little is known about whether it is worth it.

Economist, p.232. http://www.economist.com/news/leaders/21647285-more-and-moremoney-being-spent-higher-education-too-little-known-about-whether-it

Furlong, A., and F. Cartmel.(2009). Mass higher education. In A. Furlong (Ed.), Handbook of youth and young adulthood: New perspectives and agendas (pp. 121-26). London: Routledge.

Ganzeboom, H. B., De Graaf, P. M., \& Treiman, D. J. (1992). A standard international socio-economic index of occupational status. Social Science Research, 21(1), 1-56.

Ganzeboom, H. B., \& Treiman, D. J. (1996). Internationally comparable measures of occupational status for the 1988 international standard classification of occupations. Social Science Research, 25(3), 201-39.

Goldin, C. D., \& Katz, L. F. (2009). The race between education and technology. Cambridge: Harvard University Press.

Giddens, A. (1991). Modernity and self-identity: Self and society in the late modern age. Cambridge: Polity Press.

Granovetter, M. (1973). The strength of weak ties. American Journal of Sociology, 78: 1360-80.

Granovetter, M. (1974). Getting a job: A study of contacts and careers. Cambridge, MA: Harvard University Press.

Green, A. \& Mok, K.H. (2013). Expansion of higher education, gradaute employment and social mobility: An Asia and Europe dialogue. Paper presented at the 2013 Hong Kong Educational Research Association Annual Conference, Febraury 2013, Hong Kong Institute of Education. 
Guo, M. \& Wu, X. (2008). School expansion and educational stratification in China, 1981-2006. Paper presented at the conference of ISA Research Committee on Economy and Society (RC02), 26-28 June, Switzerland. http://www.wjh.harvard.edu/ hos/papers/Maocan Guo/Maocan Guo.pdf. Accessed 6 July 2012

Hawkins, J., Mok, K.H., \& Neubauer, D. (2014) Higher education massification in the Asia Pacific, Paper presented at the 2014 Senior Seminar on The Many Faces of Asia Pacific Higher Educaiton in the Massification Era, October 2014, Hong Kong Institute of Education.

Hirsch, F. (1976). Social limits to growth. Cambridge: Harvard University Press.

Haveman, R. H., \& Smeeding, T. M. (2006). The role of higher education in social mobility. The Future of Children, 16(2), 125-50.

Jiang, J. \& Tam, T. (2015). Rising class inequality of higher education during rapid college expansion in China, 1988-2002. Working Paper.

Kong, S., \& P. Sreng. (2012, November 28). The real reason for unemployment. The Phnom Penh Post, http://www.phnompenhpost.com/lift/real-reasonsunemployment.

Knight, J. B., \& Sabot, R. H. (1987). Educational expansion, government policy and wage compression. Journal of Development Economics, 26(2), 201-21.

$\mathrm{Li}, \mathrm{C}$. (2010). Expansion of higher education and inequality in opportunity of education: A study on effect of Kuozhao policy on equalization of educational attainment (gaodeng jiaoyu kuozhang yu jiaoyu jihui bupingdeng — gaoxiao kuozhao de pingdenghua xiaoying kaocha). Sociological Research (shehuixue yanjiu), 3, 82-113. (in Chinese).

Lin, N., Ensel, W. M., \& Vaughn, J. C. (1981). Social resources and strength of ties: Structural factors in occupational status attainment. American Sociological Review, 46(4), 393-405.

Liu, J. (2006). Expansion of higher education in China and inequality in entrance opportunities: 1978-2003 (gaodeng jiaoyu kuozhan yu ruxue jihui chayi: 1978-2003) Society (shehui), 26, 158-79. (in Chinese).

Lucas, S. R. (2001). Effectively maintained inequality: Education transitions, track mobility, and social background effects. American Journal of Sociology, 106(6), 164290. 
Lauder, H. (2014) Jobs or skills? The role of education in the $21^{\text {st }}$ century. Keynote speech presented at the 2014 APERA-HKERA Annual Conference, November 2014, Hong Kong Institute of Education.

Ministry of Education of the People's Republic of China. (1998). The action plan to vitalize education in the 21st century. http://www.moe.edu.cn/publicfiles/business/htmlfiles/moe/moe 177/200407/2487.html Accessed 20 April 2015 (in Chinese).

Mincer, J. (1974). Schooling, Experience, and Earnings. New York: Bureau of Economic Research.

Mok, K.H., \& Han Xiao (2015) Local responses to the central calls: Decentralization and cellularization in education governance in China, Unpublished paper.

Mok, K.H., \& Neubauer, D. (2016) Higher education governance in crisis? A critical reflection on the massification of higher education, graduate employment and social mobility. Journal of Education and Work, 29(1), 1-12.

Mok, K.H., \& Wu, A. (2016) Higher education, changing labour market and social mobility in the era of massification in China. Journal of Education and Work, 29, (1), 7797.

Mok, K.H. (2016) Transnationalizing and internationalizing higher education in China: Implications for regional cooperation and university governance in Asia. in Internationalizing higher education in Korea: Comparative perspectives. California: AsiaPacific Research centre, Stanford University.

Quinn, F., \& K. Kay. (2007, September 9). Recent graduates find job prospects are bleak. Cambodia Daily: https://www.cambodiadaily.com/archives/recentgraduates-findjob-prospects-are-bleak-1219.

Psacharopoulos, G. (1973). Returns to education: An international comparison. Amsterdam: Elsevier.

Psacharopoulos, G. (1985). Returns to education: a further international update and implications. Journal of Human Resources, 20(4), 583-604.

Psacharopoulos, G. (1994). Returns to investment in education: A global update. World Development, 22(9), 1325-43. 
Psacharopoulos, G., \& Patrinos, H. A. (2004). Returns to investment in education: a further update. Education Economics, 12(2), 111-34.

Robertson, S. L., \& Dale, R. (2013). The social justice implications of privatisation in education governance frameworks: a relational account. Oxford Review of Education, 39(4), 426-45.

Raftery, A. E., \& Hout, M. (1993). Maximally maintained inequality: Expansion, reform, and opportunity in Irish education, 1921-75. Sociology of Education, 66(1), 41-62.

Schultz, T. W. (1961). Investment in human capital. The American Economic Review, 51(1), 1-17.

Sorensen, A. B. (1979). A model and a metric for the analysis of the intergenerational status attainment process. American Journal of Sociology, 85(2), 361-84.

Tam, T., \& Jiang, J. (2014). The making of higher education inequality: How do mechanisms and pathways depend on competition? American Sociological Review, 79(4), 807-16.

Tam, T., \& Jiang, J. (2015). Divergent urban-rural trends in college attendance: State policy bias and structural exclusion in China. Sociology of Education, 88(2), 160-80

Trow, M. (1973). Problems in the transition from elite to mass higher education. In Policies for higher education, Conference on future structures of post-secondary education (pp. 55-101). Paris: Organization for Economic Cooperation and Development.

Van de Werfhorst, H. G. (2009). Credential inflation and educational strategies: A comparison of the United States and the Netherlands. Research in Social Stratification and Mobility, 27(4), 269-84.

Wan, Y. (2006). Expansion of Chinese higher education since 1998: Its causes and outcomes. Asia Pacific Education Review 7, 19-31.

Wen, D. (2005). The impacts of SES on higher education opportunity and graduate employment in China (jiating beijing dui wo guo daodeng jiaoyu jihui ji biye sheng jiuye de yingxiang). Peking University Education Review (beijing daxue jiaoyu pinglun), 3(3), 58-63. (in Chinese). 
Wen, Z., \& Ngok, K. (2011). Vulnerable college graduates: Working poor and social capital (ruoshi daxue biyesheng: zaizhi pinqiong yu shehui ziben shiye xiade "yizu"). Journal of Public Administration (gonggong xingzheng pinlun), 3, 125-145.

Wu, X., \& Treiman, D. J. (2004). The household registration system and social stratification in China: 1955-1996. Demography, 41(2), 363-384.

Wu, X., \& Treiman, D. J. (2007). Inequality and equality under Chinese socialism: The hukou system and intergenerational occupational mobility. American Journal of Sociology, 113(2), 415-45.

Yang, D. (2006). Access to higher education: Widening social class disparities (gaodeng jiaoyu ruxue jihui: kuoda zhizhong de jieceng chaju). Tsinghua Journal of Education (qinghua daxue jiaoyu yanjiu), 27, 19-25. (in Chinese)

Zhang, W. (2014). The demand for shadow education in China: Mainstream teachers and power relations. Asia Pacific Journal of Education, 34(4), 436-54.

Zhou, X., Moen, P., \& Tuma, N. B. (1998). Educational stratification in urban China: 1949-94. Sociology of Education, 71(3), 199-222.

Zinn, J. O. (2004). Health, risk and uncertainty in the life course: A typology of biographical certainty construction. Social Theory \& Health, 2(3), 199-221.

Zinn, J. O. (2008). Heading into the unknown: Everyday strategies for managing risk and uncertainty. Health, Risk \& Society, 10(5), 439-50 
Centre for Global Higher Education UCL Institute of Education London WC1H OAL

www.researchcghe.org @ResearchCGHE 